\title{
Short-term effects of spent coffee grounds on the physical properties of two Mediterranean agricultural soils**
}

\author{
Ana Cervera-Mata*, Juan Manuel Martín-García, Rafael Delgado, Jesús Párraga, \\ Manuel Sánchez-Marañón, and Gabriel Delgado
}

Department of Soil Science and Agricultural Chemistry, Universidad de Granada, 18071, Granada, Spain

Received June 28, 2018; accepted December 22, 2018

\begin{abstract}
We investigated the short-term effects of spent coffee grounds on the physical properties of two Mediterranean agricultural soils (Calcisol and Luvisol). The in vitro assay was performed with two spent coffee grounds doses (60 and $240 \mathrm{Mg}$ $\mathrm{ha}^{-1}$ ), two incubation times ( 30 and 60 days) and two modalities: with and without lettuce seedlings (Lactuca sativa var. longifolia). Spent coffee grounds addition increased water retention at -33 and $-1500 \mathrm{kPa}$, and decreased bulk density and plant-available water content. With spent coffee grounds, the percentage of macroaggregates increased, the percentage of meso- and microaggregates decreased and the structural stability of all types of aggregates increased. The stereomicroscopy images showed that: the structural aggregates were rounded, the porosity increased by $316 \%$, the structure was ordered into smaller aggregates, the incorporation of spent coffee grounds particles could occur in intraped cracks and spent coffee grounds particles could act as a binding agent. Scanning electron microscopy also showed that spent coffee grounds particles interacted with mineral particles and integrated into soil structure; moreover, fungal hyphae also developed on many spent coffee grounds particles. If spent coffee grounds effects are compared with those described in the literature for other organic amendments, the same trend was observed in most of the soil physical properties although with a different intensity, principally with regard to structural stability.

Keywords: organic amendment, soil aggregate stability, soil water retention, soil aggregate size, SEM images
\end{abstract}

\section{INTRODUCTION}

Spanish Mediterranean agricultural soils have a low organic matter content $(<1 \%$, according to Rodríguez Martín et al., 2016), which is a serious problem for soil structure

\footnotetext{
*Corresponding author e-mail: anacervera@ugr.es

**This work was supported by project AGL2014-53895-R from the Spanish Ministry of Economy and Competitiveness, by the European Regional Development Fund (FEDER) and by project CGL2016-80308-P from the Spanish Ministry of Science and Innovation (2015-2018).
}

formation and stabilization (Bronick and Lal, 2005). Thus, a reduction in organic matter content involves soil physical degradation which leads to a reduction in water and air infiltration and an increase in superficial water run-off and soil compaction (Lal, 2015). Physical soil properties such as bulk density, plant-available water, aggregate size distribution and stability, etc. (e.g. Reynolds et al., 2008), as well as organic matter content (e.g. Dexter et al., 2004) are commonly used to evaluate the physical quality of soil. Thus, a recommendable strategy to restore and improve the physical quality of Mediterranean agricultural soils is the addition of biowastes as organic amendments.

There have been many studies that have analysed the positive effect of biowastes on bulk density, water retention, plant-available water, aggregate size and structural stability (Carter, 2007; Hernández et al., 2015; Khaliq and Abassi, 2015; Aranda et al., 2016; Aranyos et al., 2016; Esmaeelnejad et al., 2016; Ferreira de Araújo et al., 2016; Forge et al., 2016; Moreno et al., 2016; Omondi et al., 2016; Sall et al., 2016; Yazdanpanah et al., 2016). These authors studied degraded soils (Arenosols, Fluvisols and Lixisols, in terms of WRB, 2014) under tropical or boreal climates, sandy textures and a lack of organic matter. These researchers attributed the improvement of the physical properties of soil to an increase in soil organic matter, the stimulation of microbial activities - which improved the soil structure through the generation of polysaccharides considered as binding agents, the hydrophobicity of incorporated materials, etc. However, comparing the effects of the different amendments is difficult, due to the enormous variability of the environmental conditions of the study sites, the chemical, physical and physicochemical characteristics of the

(C) 2019 Institute of Agrophysics, Polish Academy of Sciences 
residues and the soils studied, the various experimental conditions, etc. In addition, plant roots and their rhizosphere have many positive effects on soil aggregation, since roots and their associated microorganisms release a variety of compounds which have a cementing effect on soil particles (Bronick and Lal, 2005).

Annually, six million tonnes of spent coffee grounds (SCG) are generated from coffee infusions (Tokimoto et al., 2005). SCG are mainly biowaste compounds of carbohydrates $(82 \%)$ and proteins $(13 \%)$ with high contents of $\mathrm{K}$ and $\mathrm{P}$ (Mussatto et al., 2011). Due to its composition and structural characteristics, SCG are used as animal feed, activated carbon, carbonaceous materials, absorbents, etc., (Murthy and Naidu, 2012). SCG have also been employed as organic amendments for soils, both in their fresh form (Cruz et al., 2012, 2014a,b, 2015; Yamane et al., 2014; Hardgrove and Livesley, 2016; Cervera-Mata et al., 2018), and when composted (Cruz et al., 2014a,b).

The effect of SCG on the physical properties of soil has not been widely studied to date, since the majority of reports are only focused on the chemical and physicochemical properties of SCG (Cruz et al., 2012, 2014a,b, 2015; Yamane et al., 2014; Hardgrove and Livesley, 2016; Cervera-Mata et al., 2017). However, Hardgrove and Livesley (2016) reported that the addition of SCG increased water retention in the soil and Cervera-Mata et al. (2018) confirmed this; and also reported a decrease in bulk density.

It has been demonstrated that soil microstructure variables are very useful tools in the study of the physical quality of soils (Delgado et al., 2007; Calero et al., 2009; SánchezMarañón et al., 2011). The analyses of stereomicroscopy and SEM (scanning electron microscopy) images, allow researchers to obtain accurate data about soil porosity (shape, size, area, etc.) and soil microstructure (Delgado et al., 2007; Calero et al., 2009). Abera et al. (2017) emphasized the significance of thresholding on the study of 3D and 2D soil images.

The Mediterranean region presents irregular conditions of temperature and rainfall, which necessitated the use of soil exploratory microcosm assays as reported by Esmaeelnejad et al. (2016). In these assays, all soil-independent factors which have an influence in soil organic matter (SOM) evolution, such as temperature, humidity, biological changes, etc. (Sonnletiner et al., 2003) can be controlled.

Taking these accounts into consideration, the aim of the current research was to analyse the short-term effect of the addition of SCG as an organic amendment on soil physical properties, since there were no specific studies concerning it. An in vitro assay was carried out with two representative typologies of Mediterranean agricultural soils, poor in organic matter. The effects of other variables such as time and plant roots were also evaluated. The study of the microstructure of the soil was carried out by means of stereomicroscopy, scanning electron microscopy (SEM) and image analysis. This study was completed in order to determine whether the results obtained can contribute to the interpretation of the effects of SCG on the physical quality of the soil. Finally, the effects of SCG were compared with those of other organic amendments.

\section{MATERIALS AND METHODS}

Soil samples were collected from the topsoil (arable layer, $0-20 \mathrm{~cm}$ ) of two soils, which developed under a Mediterranean climate (Andalusia, Southern Spain): 'Vega soil' ( $37^{\circ} 14^{\prime} \mathrm{N}, 3^{\circ} 45^{\prime} \mathrm{W} 552 \mathrm{~m}$ a.s.l.) a brownishgrey (Munsell 10YR 5.5/2) Cambic Calcisol (Aric, Ochric) (IUSS Working Group WRB, 2014), and 'Red soil' $\left(36^{\circ}\right.$ $59^{\prime} \mathrm{N}, 3^{\circ} 36^{\prime} \mathrm{W} 741 \mathrm{~m}$ a.s.l.) a red (Munsell 2.5YR 4/6) Chromic Calcic Luvisol (Cutanic, Differentic, Hypereutric, Ochric) (IUSS Working Group WRB, 2014). 'Vega soil' is typically used for growing corn, alfalfa and horticultural crops under irrigation, while 'Red soil' is used for cereal crops under rain-fed conditions. The soil samples were airdried and sieved $(<2 \mathrm{~mm})$.

Coffee beans ( $100 \%$ Arabica) were supplied by a Spanish producer (Café Cumbal, S.A.). SCG were obtained by grinding $50 \mathrm{~g}$ of coffee beans (particle size between 1000 and $250 \mu \mathrm{m}$ ), and mixing them with 11 of boiling distilled water, followed by filtration and air drying.

The assay was conducted with Lactuca sativa var. longifolia, 'Little Duende'. Lactuca sativa seeds were germinated and grown for 30 days in cell flats (cell size, in $\mathrm{cm}=3 \times 3 \times 10$ ) filled with a peat and perlite mixture. The flats were placed on benches in an experimental greenhouse in Southern Spain (Saliplant S.L., Granada). The lettuce chosen; 'Little Duende' is one of the small varieties, and so it is well suited for in vitro experiments.

The assay was performed in three replicates, two different soils ('Vega soil' and 'Red soil'), three SCG doses of 0, 60 and $240 \mathrm{Mg} \mathrm{ha}^{-1}$ (equivalent to 0, 24.4 and $90.9 \mathrm{~g} \mathrm{~kg}^{-1}$ in Vega soil and $0,23.3$ and $86.3 \mathrm{~g} \mathrm{~kg}^{-1}$ in Red soil), two incubation times (30 and 60 days) and two assay modalities: with lettuce seedlings (LS) and without lettuce seedlings (WLS). A total of 72 samples were obtained. Soil control samples were used: $0 \mathrm{Mg} \mathrm{ha}{ }^{-1} \mathrm{SCG}+0$ days of incubation. These soil control samples were the same in both assay modalities.

The soil-SCG mixtures ( $400 \mathrm{~g}$ ) were transferred to PVC pots of $300 \mathrm{ml}$ capacity closed with a mesh of fibreglass at the base to avoid the loss of fine particles. Half of the pots were transplanted with 30-days-old lettuces. The WLS Pots were covered (without preventing air passage) with a plate to avoid the germination of weed seeds. To prevent leaching and water stress, the moisture level of the pots was maintained between field capacity and permanent wilting point. The irrigation requirements were measured 
by weighing, as described by Esmaeelnejad et al. (2016). The pots were irrigated every three days with distilled water: $45 \mathrm{ml}$ in pots LS and $15 \mathrm{ml}$ in pots WLS.

The assay was performed in a growth chamber under controlled conditions with a relative humidity of $60-80 \%$, temperature of $22 / 18^{\circ} \mathrm{C}$ (day/night) and $12 / 12 \mathrm{~h}$ photoperiod.

The methods of soil analyses of the American Society of Agronomy and Soil Science Society of America (Soil Survey Staff, 2014) were adopted. Granulometry analysis was determined using the Bouyoucos' method. Soil pH was measured in 1:2.5 (w/w) soil-water and in 1:5 (w/w) SCG-water suspensions. Electrical conductivity at $25^{\circ} \mathrm{C}$ $\left(\mathrm{EC}_{25}\right)$ was measured in the extract of the 1:5 $(\mathrm{w} / \mathrm{w})$ water suspension. Organic carbon (OC) was determined by hot wet oxidation (Tyurin's method). Total nitrogen was determined with a Truspec CN analyser (LECO Corporation, Saint Joseph, MI, USA). Carbonates such as $\mathrm{CaCO}_{3}(\mathrm{CAC})$ were determined using the Bernard's calcimeter method. Available phosphorus was determined using the Olsen Watanabe's method with a Helios alpha spectrophotometer (THERMO FISHER SCIENTIFIC Inc., Waltham, MA, USA). Available potassium was extracted with $1 \mathrm{~N}$ ammonium acetate $(\mathrm{pH}=7)$, and determined with a PFP7 flame photometer (JENWAY, Staffordshire, UK).

Bulk density was determined by measuring the weight of the dry air sample contained in a cylinder of known volume (Bourger's method). Water retention at $-33 \mathrm{kPa}$ (field capacity) and $-1500 \mathrm{kPa}$ (permanent wilting point) was calculated using the Richards membrane method, and plant-available water content (AW) was obtained from the difference between water retention at -33 and $-1500 \mathrm{kPa}$, employing the $\mathrm{Cm}$ coefficient. The classification of aggregates by size was performed with 250 and $1000 \mu \mathrm{m}$ sieves, differentiating between macroaggregates $(>1000 \mu \mathrm{m})$, mesoaggregates $(1000-250 \mu \mathrm{m})$ and microaggregates $(<250 \mu \mathrm{m})$. The structural stabilities of the macroaggregates and mesoaggregates were determined using the method of Kemper and Rosenau (1986), by utilizing Eijkelkamp Agrisearch Equipment (Giesbeek, NL) for wet sieving; this analysis could not be performed on microaggregates because the minimum sieve size requirement of the equipment was $250 \mu \mathrm{m}$.

The mineralogical analysis of the fine earth $(<2 \mathrm{~mm})$ was carried out by X-ray XRD (crystalline powder method). XRD spectra were obtained using a Bruker D8 Advance diffractometer.

For the study of soil microstructure, an integrated microscopy chain by reflection was applied, which consisted of stereomicroscopy and scanning electron microscopy (SEM). Stereomicroscopy images (Olympus SZX12) were captured in air-dried soil aggregates (approx. $2 \mathrm{~mm}$ ). An image analysis was performed using Image J 1.46r software on a macroaggregate fraction $(>1000 \mu \mathrm{m})$. Several morphometric characteristics were quantified: larger and smaller diameter (i.e., larger and smaller diameter of the particle's fitted ellipse), roundness (i.e. 'smaller diameter': 'larger diameter' ratio) and percentage of pores. To quantify the porosity, pores were isolated from the background following the method of Calero et al. (2009). SEM images were captured in soil aggregates $(1-2 \mathrm{~mm})$ fixed with carbon double-sided adhesive tape, metallized with carbon and analysed with a variable pressure and high resolution scanning electron microscope (VPESEM-FESEM) SUPRA40VP (ZEISS, Oberkochen, Germany), equipped with an energy dispersive X-ray (EDX) elemental analyser.

Homogeneity of variance was first assessed using the Levene's test and a significance level of $5 \%(\mathrm{p}<0.05)$. The non-dichotomous variables were studied using a one-way ANOVA. In the case of significant statistical effects (for the variables 'amount of SCG' and 'days of cultivation'), post-hoc tests (Tukey's or Dunnett's T3 test) were applied, depending on whether equal variances were assumed or not. Student's t-test was also applied for 'soil type' and 'plant' as these are dichotomous variables. When the normality was not confirmed, means were compared using the Kruskal-Wallis' test. These statistical analyses were performed with the IBM SPSS Statistics v.22.0.0.0 software package.

A principal component analysis (PCA) was performed for clustering samples and their relationships to the assay variables: SCG dose, soil type, days of cultivation and presence of plant. PCA was performed on the physical properties data matrix and preprocessed with the application of a second derivative and mean centring. This statistical treatment was performed using MATLAB 2008R (MathWorks, Natik, USA) using Eigenvector Research Inc. (Wenatchee, USA) PLS-toolbox.

\section{RESULTS}

The SCG were moderately acidic, with high organic carbon and nitrogen contents, low bulk density, and high water retention capacities at $-33 \mathrm{kPa}(118.3 \%)$ and $-1500 \mathrm{kPa}(110.4 \%)$ (Table 1). The plant-available water content was low $\left(0.37 \mathrm{~mm} \mathrm{~cm}^{-1}\right)$ due to the similarity between the amounts of water retained at both potentials.

The soils were different from each other and from SCG (Table 1). The soils were clayey, with low organic carbon and nitrogen contents and the pHs were moderately alkaline ('Vega soil') and neutral ('Red soil'). 'Vega soil' was substantially calcareous (39\% CAC) whereas 'Red soil' was less calcareous $(2 \% \mathrm{CAC})$. The water retention at -33 and $-1500 \mathrm{kPa}$, and plant-available water content were higher in 'Vega soil' than in 'Red soil'; these water retention parameters in soils were between 6 and 10 times lower than in the case of SCG. 
Table 1. Soils and spent coffee grounds properties

\begin{tabular}{|c|c|c|c|c|c|c|c|c|c|c|c|c|c|}
\hline \multirow{2}{*}{$\begin{array}{l}\text { Dry colour } \\
\text { (Munsell) }\end{array}$} & $\mathrm{CF}$ & Clay & Silt & \multirow{2}{*}{$\mathrm{pH}$} & \multirow{2}{*}{$\begin{array}{c}\mathrm{EC}_{25} \\
\left(\mathrm{dS} \mathrm{m}^{-1}\right)\end{array}$} & $\mathrm{OC}$ & $\mathrm{N}$ & \multirow{2}{*}{$\mathrm{C} / \mathrm{N}$} & CAC & \multirow{2}{*}{$\begin{array}{c}\mathrm{BD} \\
\left(\mathrm{g} \mathrm{cm}^{-3}\right)\end{array}$} & $\mathrm{W}_{33}$ & $\mathrm{~W}_{1500}$ & \multirow{2}{*}{$\begin{array}{c}\mathrm{AW} \\
\left(\mathrm{mm} \mathrm{cm}^{-1}\right.\end{array}$} \\
\hline & & $(\%)$ & & & & \multicolumn{2}{|c|}{$(\%)$} & & $(\%)$ & & \multicolumn{2}{|c|}{$(\%)$} & \\
\hline \multicolumn{14}{|c|}{ Spent coffee ground } \\
\hline $5 \mathrm{YR} / 3.5$ & & & & 5.76 & 4.5 & 59.38 & 1.87 & 32 & nd & 0.49 & 118.3 & 110.4 & 0.39 \\
\hline \multicolumn{14}{|c|}{ Vega soil } \\
\hline 10YR 5.5/2 & 2.0 & 58.0 & 29.9 & 8.2 & 1.3 & 1.36 & 0.11 & 13 & 39.0 & 1.20 & 26.4 & 15.6 & 1.30 \\
\hline \multicolumn{14}{|c|}{ Red soil } \\
\hline $2.5 \mathrm{YR} 4 / 6$ & 6.0 & 43.2 & 18.0 & 7.2 & 0.6 & 1.16 & 0.11 & 10 & 1.6 & 1.27 & 20.0 & 11.7 & 1.05 \\
\hline
\end{tabular}

$\mathrm{CF}$ - coarse fragments (whole soil), $\mathrm{EC}_{25}$ - electrical conductivity measured at $25^{\circ} \mathrm{C}, \mathrm{OC}$ - organic carbon, $\mathrm{N}-$ total nitrogen, $\mathrm{CAC}$ - carbonates as $\mathrm{CaCO}_{3}, \mathrm{BD}$ - bulk density, $\mathrm{W}_{33}$ and $\mathrm{W}_{1500}$ - water retention at -33 and $-1500 \mathrm{kPa}$, respectively, $\mathrm{AW}$ - available water, nd - not detected.

The fine earth of 'Vega soil' was rich in phyllosilicates (47\%) and carbonates (34\% calcite and 8\% dolomite), whereas 'Red soil' had more phyllosilicates (63\%) and quartz (33\%) and less carbonates.

The addition of SCG significantly increased the OC content (Tables 2 and 3). The highest dose of SCG increased OC by 313 and 339\% ('Vega soil' and 'Red soil', respectively) over the control ( $0 \mathrm{Mg} \mathrm{ha}^{-1} \mathrm{SCG}+0$ days) (Table 2$)$. No statistically significant differences were observed between $\mathrm{OC}$ and the other assay variables, although a slight decrease in OC during incubation time in samples amended SCG was observed (Table 2).

The bulk density (BD) of soils decreased as the SCG dose was increased, except for $60 \mathrm{Mg} \mathrm{ha}^{-1} \mathrm{SCG}+30$ days + WLS, which increased in 'Vega soil' and remained stable in 'Red soil' (Table 2). The percentage decrease was notably variable and ranged from a maximum of $31 \%$ for $240 \mathrm{Mg}$ $\mathrm{ha}^{-1} \mathrm{SCG}+60$ days + WLS in 'Vega soil' (BD from 1.20 to $0.96 \mathrm{~g} \mathrm{~cm}^{-3}$ ) to a minimum of $8 \%$ for $0 \mathrm{Mg} \mathrm{ha}^{-1}+60$ days + LS, also in 'Vega soil' (BD from 1.20 to $1.11 \mathrm{~g} \mathrm{~cm}^{-3}$ ). The BD decreased significantly with time (Table 3 ), according to the equation ' $\mathrm{BD}\left(\mathrm{g} \mathrm{cm}^{-3}\right)=1.145-0.002 \times$ time (days)' $(r=-0.587 ; \mathrm{p}<0.001)$. This property was also significantly higher in 'Red soil' than in 'Vega soil' ( $p<0.05$; Table 3$)$. No significant relationship was found with the presence of LS.

The addition of SCG increased water retention at $-33 \mathrm{kPa}$ $\left(\mathrm{W}_{33}\right)$ and $-1500 \mathrm{kPa}\left(\mathrm{W}_{1500}\right)$ (Table 2). A dose of $60 \mathrm{Mg}$ ha $^{-1}$ SCG increased $W_{33}$ by $11 \%$ and $W_{1500}$ by $19 \%$ over the control. A dose of $240 \mathrm{Mg} \mathrm{ha}^{-1} \mathrm{SCG}$ increased $\mathrm{W}_{33}$ by $40 \%$ and $\mathrm{W}_{1500}$ by $108 \%$ over the control. The influence of the SCG dose on water retention was significant (Table 3) and so were the correlations; 'SCG dose' versus ' $\mathrm{W}_{33}$ ', $(r=0.672 ; \mathrm{p}<0.001)$ and 'SCG dose' versus ' $\mathrm{W}_{1500}$ ', $(r=0.892 ; \mathrm{p}<0.001) . \mathrm{W}_{33}$ increased more in 'Vega soil' than in 'Red soil' and $\mathrm{W}_{1500}$ increased more in 'Red soil' than in 'Vega soil'. These increases are significant in both cases: $\mathrm{p}<0.001$ for $\mathrm{W}_{33}$ and $\mathrm{p}<0.05$ for $\mathrm{W}_{1500}$ (Table 3$)$. No statistically significant relationship was observed between water retention and time.

Plant-available water content (AW) decreased in both soils when SCG was added. In 'Vega soil', the values of $1.30 \mathrm{~mm} \mathrm{~cm}^{-1}$ in the control sample reached a minimum value of $0.22 \mathrm{~mm} \mathrm{~cm}^{-1}$ for $240 \mathrm{Mg} \mathrm{ha}^{-1} \mathrm{SCG}+60$ days + LS (Table 2). In 'Red soil', values of $1.05 \mathrm{~mm} \mathrm{~cm}^{-1}$ in the control sample reached a minimum value of $0.12 \mathrm{~mm} / \mathrm{cm}$ for $240 \mathrm{Mg} \mathrm{ha}^{-1} \mathrm{SCG}+60$ days + WLS. SCG dose and soil type had a significant influence on AW ( $p<0.001$ and $\mathrm{p}<0.05$, respectively, Table 3 ). The significant effect of SCG is also corroborated by the correlation of 'SCG dose' versus ' $A W$ ' $(r=-0.711 ; \mathrm{p}<0.001)$.

The percentage of macroaggregates increased during incubation when SCG was added (except for $240 \mathrm{Mg} \mathrm{ha}^{-1}$ SCG + LS in 'Vega soil'), and this variable increased during the first 30 days and subsequently decreased in samples without SCG addition (Table 2). There was a significant relationship between the percentage of macroaggregates and time, but with SCG there was none (Table 3). The equation which shows the relationship between the percentage of macroaggregates and time is: 'macroaggregates $(\%)=29.834+0.591 \times$ time (days)' $(r=0.619 ; \mathrm{p}<0.001)$. On the contrary, the percentage of meso- and microaggregates decreased during incubation time in samples mixed with SCG (Table 2). The relationship between SCG and these properties was highly significant (Table 3): 'mesoaggregates $(\%)=23.644-0.322 \times$ time (days)' $(r=-0.456$; $\mathrm{p}<0.001)$; 'microaggregates $(\%)=46.530-0.269 \times$ time (days)' $(r=-0.696 ; \mathrm{p}<0.001)$.

The percentages of stable macro- and mesoaggregates increased by SCG addition and incubation time reached maximum values of $94 \%$ (macroaggregates) and $98 \%$ (mesoaggregates) when $240 \mathrm{Mg} \mathrm{ha}^{-1} \mathrm{SCG}$ was added (Table 2). The correlations of 'SCG dose' versus 'stable macroaggregates' $(r=0.741 ; \mathrm{p}<0.001)$ and 'SCG dose' versus 'stable mesoaggregates' $(r=0.554 ; \mathrm{p}<0.01)$ were highly 


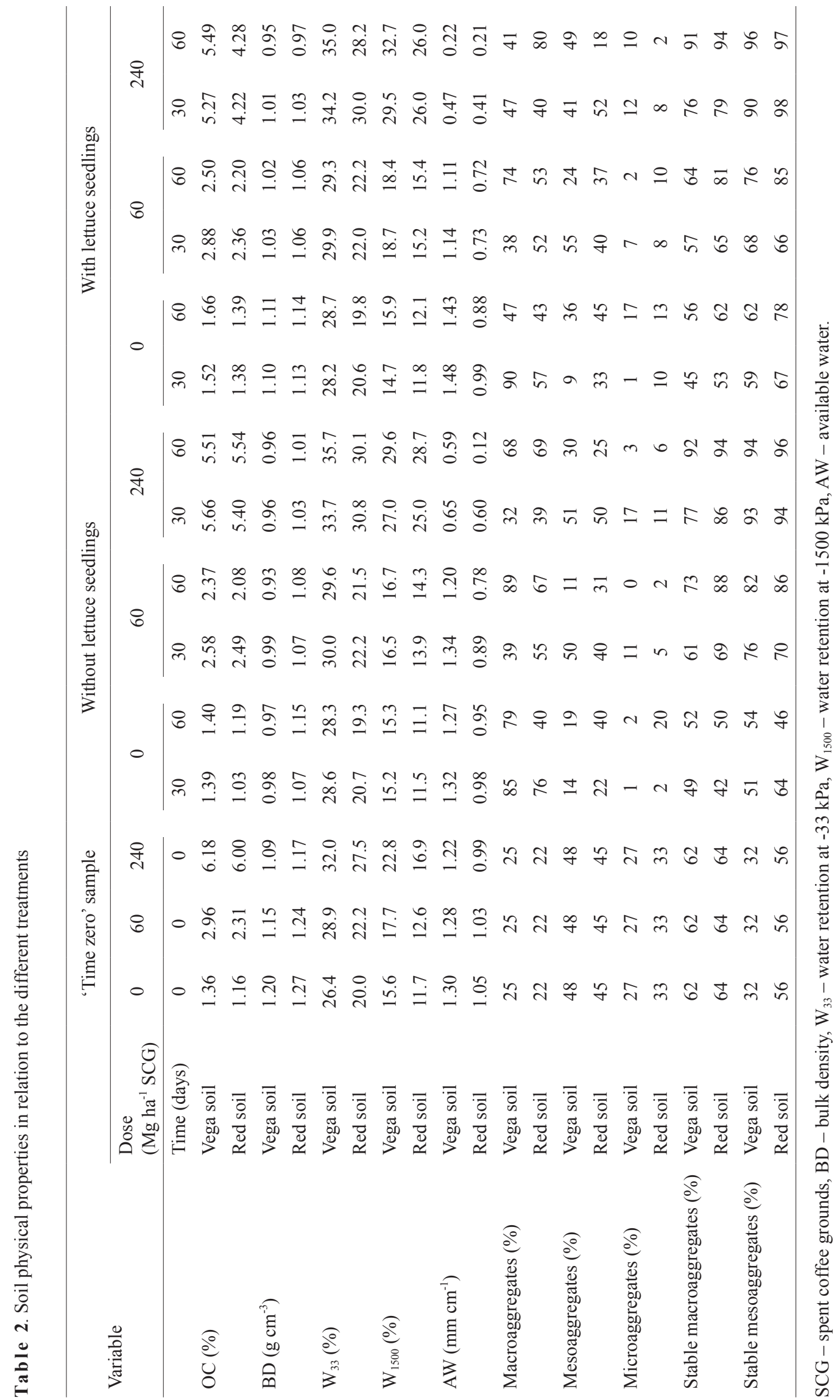


Table 3. One way ANOVA analysis and Student's t-test

\begin{tabular}{llll}
\hline \multirow{2}{*}{ Variable } & \multicolumn{2}{c}{ ANOVA } & $\begin{array}{c}\text { Student`s } \\
\text { t-test }\end{array}$ \\
\cline { 2 - 4 } & SCG & Time & Soil type \\
\hline OC & $<0.001^{*}$ & & \\
$\mathrm{BD}$ & & $<0.001^{*}$ & $<0.05+$ \\
$\mathrm{W}_{33}$ & $<0.01^{* * *}$ & & $<0.001+$ \\
$\mathrm{W}_{1500}$ & $<0.001^{* * *}$ & & $<0.05+$ \\
$\mathrm{AW}$ & $<0.001^{* *}$ & & $<0.05+$ \\
Macroaggregates & & $<0.001^{* *}$ & \\
Mesoaggregates & & $<0.05^{* *}$ & \\
Microaggregates & & $<0.01 * *$ & \\
Stable macroaggregates & $<0.001^{*}$ & & \\
Stable mesoaggregates & $<0.01^{*}$ & $<0.001^{*}$ & \\
\hline
\end{tabular}

SCG - spent coffee grounds, OC - organic carbon, BD - bulk density, $\mathrm{W}_{33}$ - water retention at $-33 \mathrm{kPa}, \mathrm{W}_{1500}$ - water retention at $-1500 \mathrm{kPa}, \mathrm{AW}$ - available water. ${ }^{*} \mathrm{p}$ values from one way ANOVA. Means were compared by Tukey's test, since the homogeneity of variances was confirmed by Levene's test ( $p>$ $0.05)$. **p values from one way ANOVA. Means were compared by Dunnett's T3 test, since the homogeneity of variances was not confirmed by Levene's test $(\mathrm{p}<0.05)$. ***p values from one way ANOVA on ranks. Means were compared by the KruskalWallis test, since the normality of the data was not confirmed by the Shapiro-Wilks' test $(\mathrm{p}<0.05)$. ${ }^{+}$Means were compared by Student's t-test, since the homogeneity of variances was not confirmed by Levene's test $(p>0.05)$. The results for plant are not included because they are not significant.

significant. A positive and significant correlation between the time of experimentation and the percentage of stable mesoaggregates $(r=0.589 ; \mathrm{p}<0.001)$ was also observed.

Stereomicroscopy images of aggregates indicate that they were, according to the Soil Science Division Staff (2017), granular in the control samples and crumb-like (more porous) in the incubated samples, with or without SCG addition (e.g. 'Vega soil', Fig. 1). For the study of roundness and porosity variables by means of image analysis, the macroaggregate fraction $(>1000 \mu \mathrm{m})$ was selected (Table 4). The addition of SCG and sufficient incubation time increased roundness and porosity, although these relationships are significant only in the case of porosity $(\mathrm{p}<0.001)$. The increase in porosity may be observed in Fig. $1 \mathrm{~b}$ and $1 \mathrm{c}$ and it was corroborated by image analysis (Table 4). The porosity changed from $2.10 \%$ in the Control samples to 7.03 and $8.00 \%$ in $0 \mathrm{Mg} \mathrm{ha}^{-1}+60$ days and 240 $\mathrm{Mg} \mathrm{ha}^{-1}+60$ days samples, respectively (Fig. 1). Over time, a hierarchy of aggregates in micropeds smaller than $1 \mathrm{~mm}$ was observed (Fig. 1b and 1c). Moreover, it seems that SCG were incorporated into intraped cracks (Fig. 1c).

The SEM study (Fig. 2) also corroborated the abovementioned results. Thus, the relative porosity and a hierarchy of aggregates in micropeds (approx. $100 \mu \mathrm{m}$ ) were determined
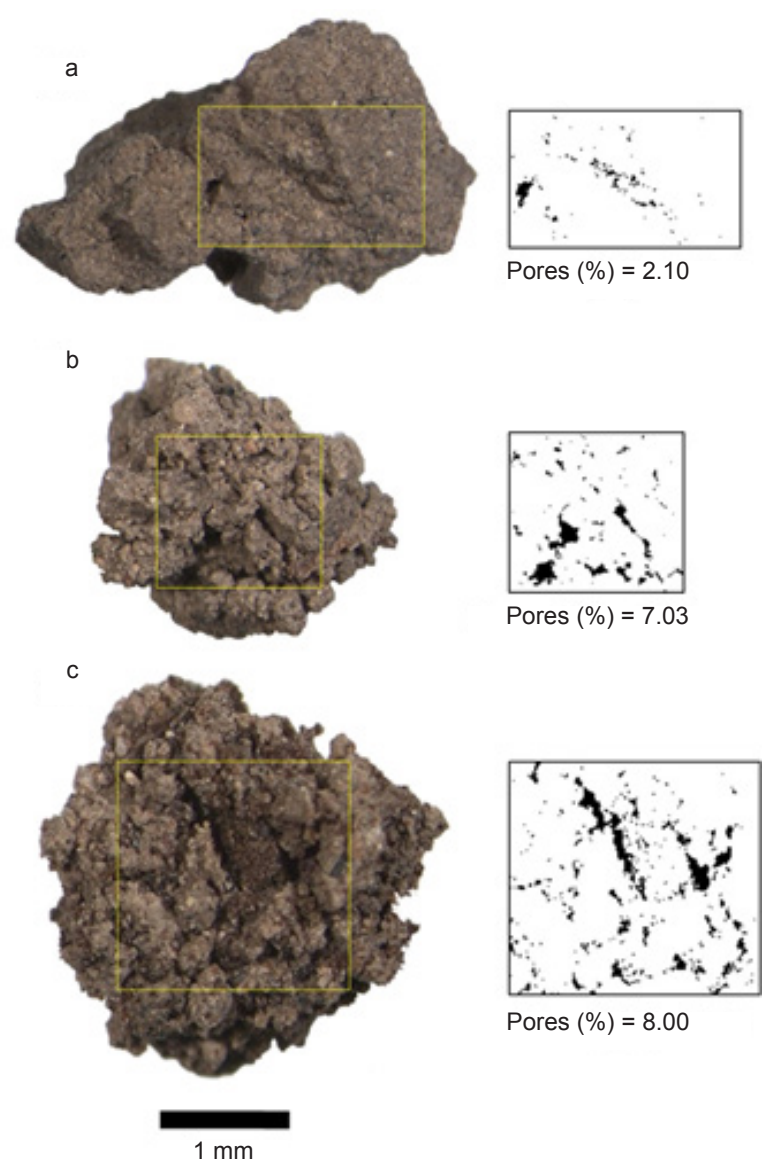

Fig. 1. Stereomicroscopy images of macroaggregates corresponding to 'Vega soil' and image analysis results: a $-0 \mathrm{Mg} \mathrm{ha}^{-1} \mathrm{SCG}$ +0 days, $\mathrm{b}-0 \mathrm{Mg} \mathrm{ha}^{-1} \mathrm{SCG}+60$ days + without $\mathrm{LS}, \mathrm{c}-240 \mathrm{Mg}$ $\mathrm{ha}^{-1} \mathrm{SCG}+60$ days + without LS.

for the sample $0 \mathrm{Mg} \mathrm{ha}^{-1} \mathrm{SCG}+60$ days + WLS of 'Vega soil' (Fig. 2a). Its EDX spectrum is characteristic of soil mineral particles, principally aluminosilicates and calcium carbonates, as evidenced in the mineralogy, which is typical of a Cambic Calcisol. Figure $2 b$ shows how the particle of SCG is incorporated into the soil mass, with a coating of mineral particles. The SCG particles have a vacuolar appearance (Fig. 2b and 2c) due to the toasting process which generated cavities in the coffee grains through $\mathrm{CO}_{2}$ release, whereas its cuticle remains unchanged (Fadai et al., 2017). Many SCG particles incorporated into soil were colonized by fungal hyphae (Fig. 2d).

A principal component analysis (PCA) was carried out in order to evaluate the influence of the assay variables: 'SCG dose', 'soil type' and 'plant'. Three PCs captured $90.5 \%$ of the variance (Fig. 3). In Fig. 3a the score values of the samples in the space defined by $\mathrm{PC} 1$ and $\mathrm{PC} 2$ are shown. Samples with $240 \mathrm{Mg} \mathrm{ha}^{-1}$ SCG are clearly distinguished from samples with $0 \mathrm{Mg} \mathrm{ha}^{-1}$ and among them are those of $60 \mathrm{Mg} \mathrm{ha}^{-1} \mathrm{SCG}$. In the space defined by PC1 
Table 4. Microfabric parameters of the soil and soil-SCG samples measured with stereomicroscope and image analysis (mean \pm SD)

\begin{tabular}{lcccccc}
\hline Soil & $\begin{array}{c}\text { SCG } \\
\left(\mathrm{Mg} \mathrm{ha}^{-1}\right)\end{array}$ & $\begin{array}{c}\text { Time } \\
(\text { days })\end{array}$ & $\begin{array}{c}\text { Larger diameter } \\
(\mathrm{mm})\end{array}$ & $\begin{array}{c}\text { Smaller diameter } \\
(\mathrm{mm})\end{array}$ & Roundness & $\begin{array}{c}\text { Pores } \\
(\%)\end{array}$ \\
\hline \multirow{2}{*}{ 'Vega soil' } & 0 & 0 & $2.55 \pm 0.814$ & $1.75 \pm 0.515$ & $0.69 \pm 0.132$ & $2.29 \pm 1.166$ \\
& 0 & 60 & $2.37 \pm 0.353$ & $1.84 \pm 0.256$ & $0.78 \pm 0.082$ & $6.61 \pm 0.931$ \\
& 240 & 60 & $2.42 \pm 0.315$ & $1.99 \pm 0.508$ & $0.82 \pm 0.115$ & $10.33 \pm 2.218$ \\
'Red soil' & 0 & 0 & $2.66 \pm 0.532$ & $1.89 \pm 0.271$ & $0.71 \pm 0.078$ & $2.72 \pm 1.047$ \\
& 240 & 60 & $2.45 \pm 0.377$ & $1.83 \pm 0.330$ & $0.75 \pm 0.115$ & $7.45 \pm 0.727$ \\
\hline
\end{tabular}

SCG - spent coffee grounds. The values correspond to the mean of samples LS and WLS. The mean differences for the parameters 'larger diameter', 'smaller diameter' and 'roundness' are not significant; the mean differences for the 'pores' parameter are significant $(\mathrm{p}<0.001)$.
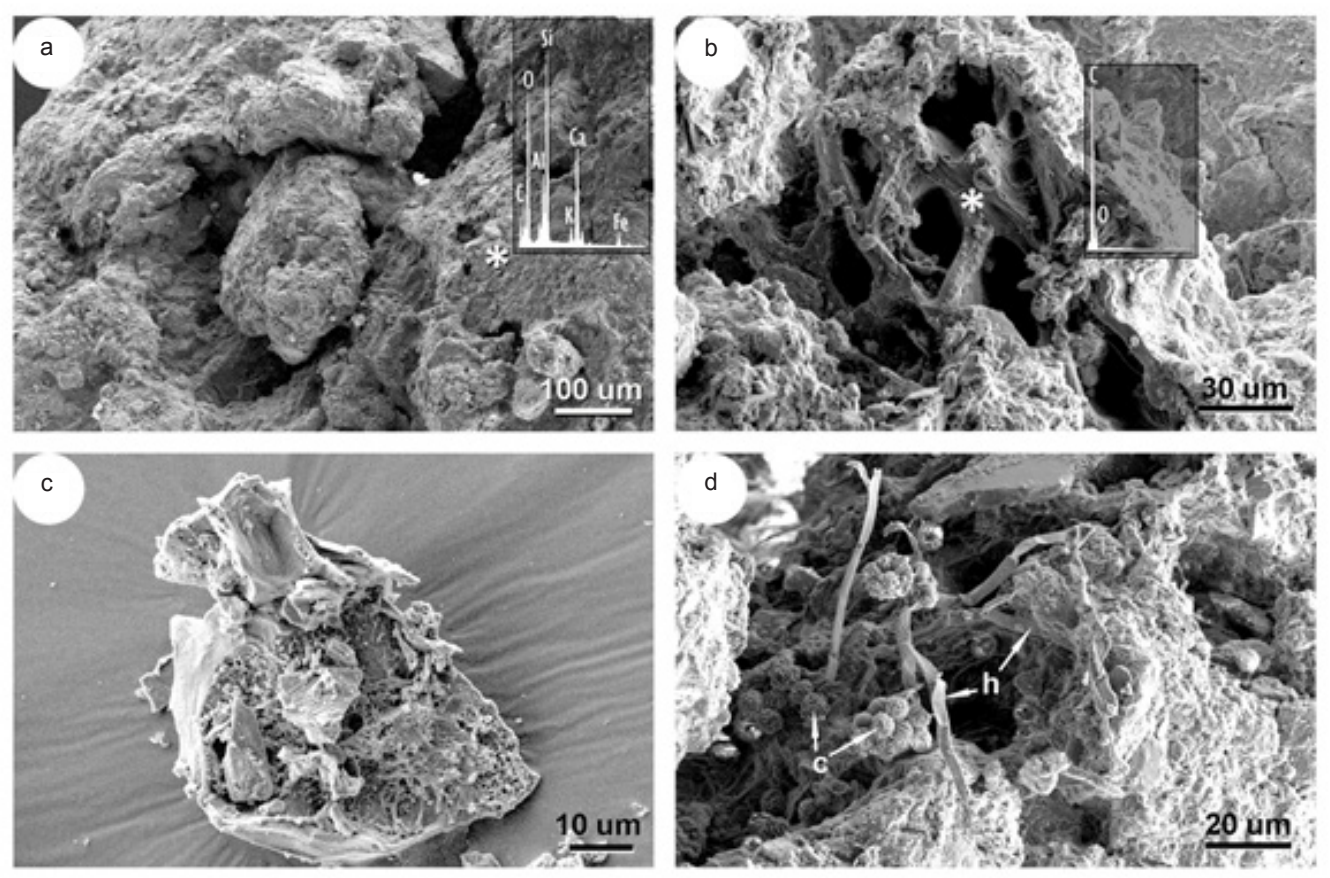

Fig. 2. SEM images with secondary electrons and EDX spectra (the white dot indicates the site of microanalysis): a - 'Vega soil' $0 \mathrm{Mg}$ $\mathrm{ha}^{-1} \mathrm{SCG}+60$ days + without LS; b - 'Vega soil' $240 \mathrm{Mg} \mathrm{ha}^{-1} \mathrm{SCG}+60$ days + without LS. A particle of SCG may be seen bonded to the soil surface and partially covered with inorganic particles; c - SCG particle; d - 'Vega soil' $240 \mathrm{Mg}^{-1} \mathrm{SCG}+60$ days + without LS. Fungal hyphae (h) with conidiophores (c) can be observed.

and PC3 (Fig. 3b), the samples were clearly separated by soil type. PC1 versus PC2 separated the samples regarding the time of experimentation (Fig. 3c), with a clear separation between control samples and incubated samples; no clear discrimination between 30 and 60 days was observed. The variable plant did not discriminate between samples (Fig. 3d). In conclusion, clear groupings may be observed regarding the SCG dose, soil type and time of experimentation. In the literature that is related to other organic amendments, the dose of residue (e.g. Omondi et al., 2016) and incubation time (e.g. Diacono and Montemurro, 2009) were the variables that showed a greater influence on the final result.

\section{DISCUSSION}

As stated above, to date, there are no specific studies about the influence of SCG on the physical properties of soil but there are some for other organic amendments. To compare the results obtained from the current study with the literature, the 'response ratio' (RR) was estimated using the following formula (Omondi et al., 2016): $\mathrm{RR}=\mathrm{Xt} / \mathrm{Xc}$; where, $\mathrm{Xt}$ is the mean of the organic amendment treated group and $\mathrm{Xc}$ is the mean of the control group for a given experiment. Therefore, the RR indicates the increase or decrease regarding the reference level $(R R=1)$. For the current report, the average RR at 60 days was calculated; the calculated RR of the current study and those calculated with the data of the bibliography are shown in Table 5. 
a

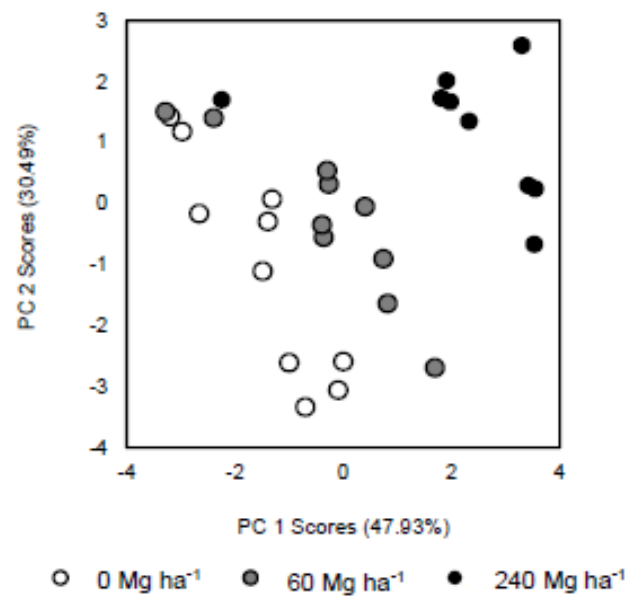

c

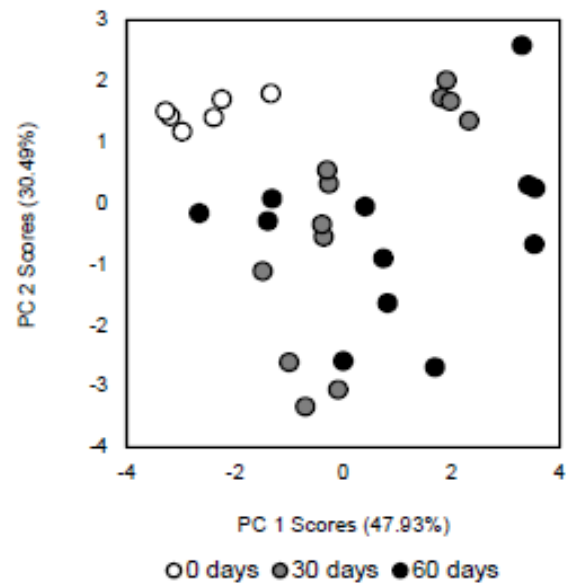

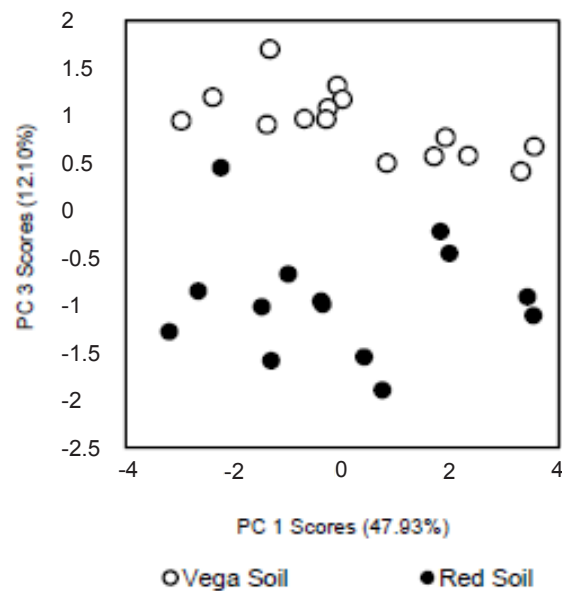

d

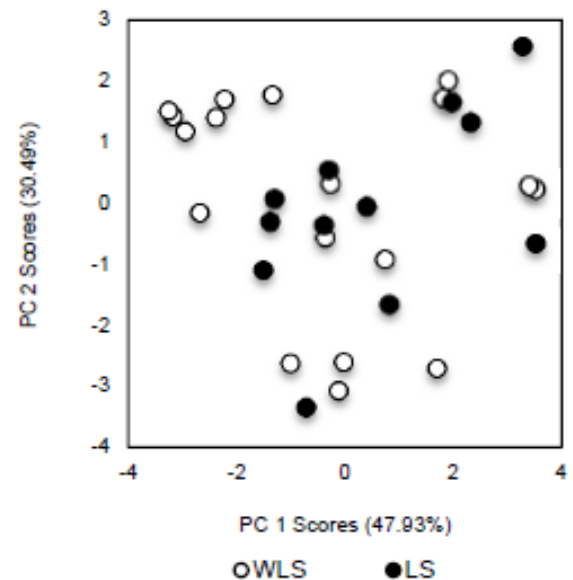

Fig. 3. PCA scatter plot of soil samples. PC1 + PC2 + PC3 capture 90.5\% of the variance (sum of its scores): a - PC2 versus PC1: discrimination by 'SCG dose' $\left(\mathrm{Mg} \mathrm{ha}^{-1}\right)$; b - PC2 versus $\mathrm{PC} 1$ : discrimination by 'time of experimentation'; $\mathrm{c}-\mathrm{PC} 3$ versus $\mathrm{PC} 1$ : discrimination by 'soil type'; d-PC2 versus PC1: discrimination by 'plant'. WLS - without lettuce seedlings, LS - with lettuce seedlings.

The decrease in BD due to the addition of SCG and the time of experimentation (Table 2) is in accordance with the $\mathrm{RR}$ values (Table 5). This decrease is in accordance with previous literature for other organic amendments. The RRs calculated with the data of these authors are between 0.96 and 0.85 (Table 5). Similar results were obtained in the current study with a shorter time but higher dose of residue; therefore it is erroneous to state that SCG are better than other wastes with regards to BD decrease. In other assays, the decrease in BD is directly attributed to the increase in organic matter in the soil (Aranyos et al., 2016; Khaliq and Abassi, 2015) which increases the porosity according to Moreno et al. (2016). The increase in porosity noted by the current research was verified by means of observation with a stereomicroscope (Fig. 1), but it could not be exclusively attributed to an increase in $\mathrm{OC}$ as a result of SCG addition (Table 2), but also to the time factor (Fig. 1b). The effect of time may be attributed to the moisture oscillations that occurred during the experiment and also to biological activities (Bronick and Lal, 2005). Moisture changes, accord- ing to these authors, had an effect on the increase in soil porosity and also on the incorporation of particulate organic materials (such as SCG, Fig. 1c) within the aggregates.

The increase in $\mathrm{W}_{33}$ and $\mathrm{W}_{1500}$ due to the addition of SCG and the time of experimentation (Table 2) is in accordance with the RR values (Table 5). Thus, the relative increase in $\mathrm{W}_{1500}$ was greater than it was for $\mathrm{W}_{33}$. The RRs for both potentials, calculated with Carter's data (2007) were very similar to each other (Table 5), and differ from the results of the current study. On the other hand, the results of Aranda et al. (2016) were similar to those of the current research with regard to the relative increase between the two potentials (greater for $\mathrm{W}_{1500}$ ). It may be argued that the type of waste influences the relative increase in water retention at different potentials and that, in general, the SCG, in relation to other organic amendments, increased $\mathrm{W}_{1500}$ to a greater extent.

The addition of SCG decreased AW, which led to an RR $<1$ (Table 5). This effect is also observed in Fig. 4, where the water retention at the two potentials versus SCG dose, is shown. The vertical distance between the two straight 
Table 5. Response ratio for spent coffee grounds and other organic amendments

\begin{tabular}{|c|c|c|}
\hline Property & $\begin{array}{c}\text { Response } \\
\text { ratio } \\
(\mathrm{RR})\end{array}$ & Reference \\
\hline \multirow[t]{10}{*}{$\mathrm{BD}$} & $<1$ & Omondi et al. $(2016)^{\mathrm{a}}$ \\
\hline & 0.96 & Aranyos et al. $(2016)^{\mathrm{b}}$ \\
\hline & 0.95 & Moreno et al. $(2016)^{\mathrm{c}}$ \\
\hline & 0.94 & our data $^{\mathrm{d}}$ \\
\hline & 0.92 & Carter $(2007)^{\mathrm{e}}$ \\
\hline & 0.90 & Khaliq and Abassi $(2015)^{\mathrm{f}}$ \\
\hline & 0.90 & our data ${ }^{\mathrm{g}}$ \\
\hline & 0.89 & Forge et al. $(2016)^{\mathrm{h}}$ \\
\hline & 0.88 & Aranda et al. $(2016)^{\mathrm{i}}$ \\
\hline & 0.85 & Ferreira de Araújo et al. (2016) \\
\hline \multirow[t]{4}{*}{$\mathrm{W}_{33}$} & 1.37 & our data ${ }^{g}$ \\
\hline & 1.30 & Aranda et al. $(2016)^{\mathrm{i}}$ \\
\hline & 1.17 & Carter $(2007)^{\mathrm{e}}$ \\
\hline & 1.08 & our data ${ }^{\mathrm{d}}$ \\
\hline \multirow[t]{6}{*}{$\mathrm{W}_{1500}$} & 2.31 & Aranda et al. $(2016)^{\mathrm{i}}$ \\
\hline & 2.19 & our data ${ }^{\mathrm{g}}$ \\
\hline & 1.44 & Forge et al. $(2016)^{\mathrm{h}}$ \\
\hline & 1.20 & our data ${ }^{\mathrm{d}}$ \\
\hline & 1.11 & Carter $(2007)^{\mathrm{e}}$ \\
\hline & 0.96 & Moreno et al. $(2016)^{\mathrm{c}}$ \\
\hline \multirow{5}{*}{$\begin{array}{l}\text { Available } \\
\text { water }\end{array}$} & $>1$ & Omondi et al. $(2016)^{\mathrm{a}}$ \\
\hline & 1.16 & Moreno et al. $(2016)^{\mathrm{c}}$ \\
\hline & 0.90 & Forge et al. $(2016)^{\mathrm{h}}$ \\
\hline & 0.84 & our data ${ }^{\mathrm{d}}$ \\
\hline & 0.25 & our data ${ }^{\mathrm{g}}$ \\
\hline \multicolumn{3}{|c|}{ Aggregate size $(\mu \mathrm{m})$} \\
\hline$>2000$ & 7.14 & Sall et al. $(2016)^{\mathrm{k}}$ \\
\hline $2000-250$ & 0.61 & Sall et al. $(2016)^{\mathrm{k}}$ \\
\hline $250-50$ & 0.83 & Sall et al. $(2016)^{\mathrm{k}}$ \\
\hline$<50$ & 0.55 & Sall et al. $(2016)^{\mathrm{k}}$ \\
\hline$>1000$ & 1.40 & our data ${ }^{d}$ \\
\hline$>1000$ & 1.33 & our data ${ }^{\mathrm{g}}$ \\
\hline $1000-250$ & 0.71 & our data ${ }^{\mathrm{d}}$ \\
\hline $1000-250$ & 0.99 & our data ${ }^{g}$ \\
\hline$<250$ & 0.25 & our data ${ }^{\mathrm{d}}$ \\
\hline$<250$ & 0.64 & our data ${ }^{g}$ \\
\hline \multirow{7}{*}{$\begin{array}{l}\text { Stable } \\
\text { aggregates (us) }\end{array}$} & $>1$ & Omondi et al. $(2016)^{\mathrm{a}}$ \\
\hline & 1.91 & Hernández et al. $(2016)^{1}$ \\
\hline & 1.62 & Ferreira de Araújo et al. (2016) \\
\hline & 1.38 & Yazdanpanah et al. $(2016)^{\mathrm{m}}$ \\
\hline & 1.26 & Khaliq and Abassi (2015) \\
\hline & 1.07 & Carter $(2007)^{e}$ \\
\hline & 1.06 & Forge et al. $(2016)^{\mathrm{h}}$ \\
\hline \multirow{2}{*}{$\begin{array}{l}\text { Stable macro- } \\
\text { aggregates }\end{array}$} & 1.40 & our data ${ }^{\mathrm{d}}$ \\
\hline & 1.70 & our data ${ }^{\mathrm{g}}$ \\
\hline \multirow{2}{*}{$\begin{array}{l}\text { Stable meso- } \\
\text { aggregates }\end{array}$} & 1.43 & our data ${ }^{\mathrm{d}}$ \\
\hline & 1.66 & our data ${ }^{g}$ \\
\hline
\end{tabular}

${ }^{a}$ Biochar (different temperatures and particle size) $\left(20-80 \mathrm{Mg} \mathrm{ha}^{-1}\right)$; ${ }^{\mathrm{b}}$ composted sewage sludge (27 $\mathrm{Mg} \mathrm{ha}^{-1}$ ) during 1-4 years in an

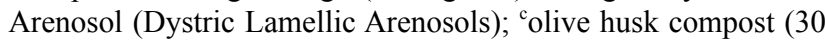
$\left.\mathrm{Mg} \mathrm{ha}^{-1}\right)$ during 5 years; ${ }^{\mathrm{d}}$ spent coffee grounds $\left(60 \mathrm{Mg} \mathrm{ha}^{-1}\right)$ during 60 days (Vega and Red soils); 'compost (potato, sawdust, manure volume ratio of $3: 3: 1)\left(13-17 \mathrm{Mg} \mathrm{ha}^{-1}\right)$ during 12 years in a Finey sandy loam (OrthicHumo-Ferric Podzol); ${ }^{\mathrm{f}}$ poultry manure and wheat straw residues ( $\left.11 \mathrm{Mg} \mathrm{ha}^{-1}\right)$ during 3 years in a Humic Lithic Eutrudepts (Inceptisols); ${ }^{\mathrm{g}}$ spent coffee grounds $(240 \mathrm{Mg}$ $\mathrm{ha}^{-1}$ ) during 60 days (Vega and Red soils); ${ }^{\mathrm{h}}$ compost and poultry manure $\left(290 \mathrm{Mg} \mathrm{ha}^{-1}\right)$ during 1 year in a Orthic Humo-Ferric Podzol; i Olive mill pomace co-compost (6-10 $\mathrm{Mg} \mathrm{ha}^{-1}$ ) during 17 years in calcareous and siliceous soils; ${ }^{\mathrm{j}}$ composted tannery sludge $\left(20 \mathrm{Mg} \mathrm{ha}^{-1}\right)$ during 6 years in a Neossolo Fluvico; ${ }^{\mathrm{k}}$ Zea mays and Crotalaria retusa $\left(5 \mathrm{Mg} \mathrm{ha}^{-1}\right)$ during 120 days in a Deck-dior soil, fine sandy, mixed Haplic Ferric Lixisol; 'composted urban waste $\left(450 \mathrm{Mg} \mathrm{ha}^{-1}\right)$ during 5 years in a semiarid degraded soil; ${ }^{\mathrm{m}}$ urban municipal solid waste compot and alfafa residue $\left(30 \mathrm{Mg} \mathrm{ha}^{-1}\right)$ during 2 years in a clay loam and loamy sand soil. us, unspecific size. $\mathrm{SCG}$ - spent coffee grounds, $\mathrm{BD}$ - bulk density, $\mathrm{W}_{33}$ - water retention at $-33 \mathrm{kPa}, \mathrm{W}_{1500}-$ water retention at $-1500 \mathrm{kPa}$.

lines is equal to AW. The decrease in $\mathrm{AW}$ is in accordance with the results of Forge et al. (2016) and Aranda et al. (2016) (Table 5). The latter author attributed this decrease to the hydrophobicity of the amendment employed (olivemill pomace co-compost). Carter (2007) also included in his research a graph similar to Fig. 4 , in which both straight lines are almost parallel, which means that AW does not decrease. On the other hand, Moreno et al. (2016) and Omondi et al. (2016) found an RR $>1$ due to the increase in AW due to organic amendment addition. Therefore, it may be stated that the effects of the organic amendments on AW do not depend only on the increase in organic matter, but also on its nature.

In general, SCG addition and time of incubation increased the percentage of macroaggregates and decreased the percentage of meso- and microaggregates (Table 2), which is also in accordance with RR values (Table 5). This response is in accordance with previous reports for other wastes (Sall et al. 2016), however, the effect of SCG on aggregate size was lower. Thus, the RR for the largest aggregates reported by Sall et al. (2016) is 7.14 and the $\mathrm{RR}$ of the current research for macroaggregates is 1.40 (Table 5). The increase in aggregate size, according to Bronick and Lal (2005), occurred in accordance with the hierarchical theory of aggregation: microaggregates join together to form macroaggregates. This is also in accordance with the observations shown in Fig. 1c, where an aggregate of almost $3 \mathrm{~mm}$ is formed by smaller microaggregates $(<1 \mathrm{~mm})$. According to Sall et al. (2016) and Esmaeelnejad et al. (2016), an increase in aggregate size is partially due to fungal activities. A colonization of the soil by fungal hyphae through SCG addition is observed in Fig. $2 b$, which may be considered a cause of macroaggregate formation in this assay. 


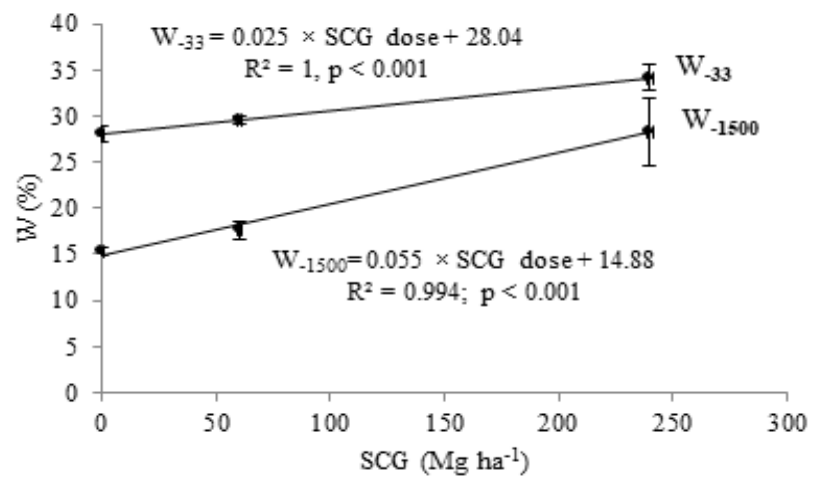

b

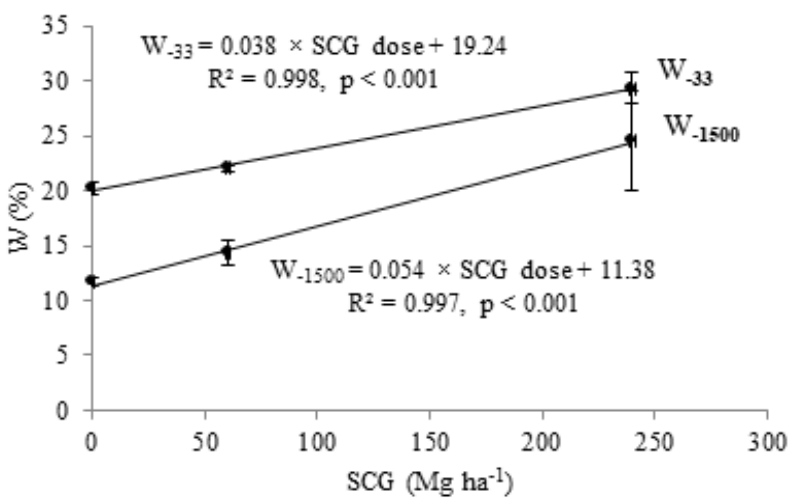

Fig. 4. Water retention at field capacity and permanent wilting point versus SCG dose. The vertical distance between the two straight lines is equal to AW. W - water retention (\%), SCG spent coffee grounds $\left(\mathrm{Mg} \mathrm{ha}^{-1}\right), \mathrm{W}_{33}$ - water retention at $-33 \mathrm{kPa}$, $\mathrm{W}_{1500}$, water retention at $-1500 \mathrm{kPa}$. a - Vega soil, b - Red soil.

SCG addition and time of incubation increased the percentage of stable macro- and mesoaggregates (Table 2), which is in accordance with RR $>1$ (Table 5). The increase in structural stability through organic amendments addition is widely described in the literature, however in these reports it is not differentiated by aggregate size. The addition of a large amount of organic matter and the passage of time are related to the highest RR value. SCG addition has a rapid impact on structural stability: 60 days of incubation with SCG has the same effect as 12 years with other residues (Carter, 2007). The increase in structural stability can be attributed to the development of the roots, which are stimulated by the addition of the organic amendment (Forge et al., 2016). In this experiment, the structural stability could not be related to the roots since the presence of the plant has no significant effect on physical properties. According to Yazdanpanah et al. (2016), the polysaccharides generated by microorganisms act as binding agents and increase the stability of the aggregate. An increase in the number of fungal hyphae was observed when SCG was added (Fig. 2d), which could lead to an increase in binding agents. In the same way, the interaction between
SCG particles (particulate organic matter) and soil mineral particles (Figs 1c and 2b) also has a stabilizing effect on aggregates. Interactions between elements of the organic matter (increased significantly by SCG addition) and the mineral particles contributed to the structural stability (Bronick and Lal, 2005).

The effects of the addition of SCG and the time of experimentation on physical properties have the same trend in 'Vega soil' and 'Red soil', although significant differences have been found between the two soils in the variables $\mathrm{BD}, \mathrm{W}_{33}, \mathrm{~W}_{1500}$ and AW (Table 3). These differences can be attributed to the fact that both soils have different chemical, physicochemical and mineralogical properties (Tables 1 and 2). In order to better understand the influence of soil properties on the effects of SCG as an organic amendment, it would be necessary to carry out an experiment where a greater number of soils with different properties are used.

Although it is indicated in the literature that plants roots have positive effects on soil aggregation (Bronick and Lal, 2005; Forge et al., 2016), this has not been demonstrated by the current research. The reason for this could be that the effect of SCG could mask the effect of plant roots.

\section{CONCLUSIONS}

1. The addition of spent coffee grounds in two Mediterranean agricultural soils increased water retention at field capacity and permanent wilting point, it also increased the percentage of macroaggregates and structural stability; while simultaneously decreasing bulk density, plant-available water content and the percentage of meso- and microaggregates. Among the short-term effects on the physical properties of soil, caused by the addition of spent coffee grounds, the increase in structural stability is emphasized

2 . The greater the spent coffee grounds dose and time of experimentation, the greater the effects on physical properties.

3. The soil type also had a significant influence on the intensity, but not on the results of the spent coffee grounds effects.

4. The presence of the plant had no significant influence on any soil physical properties.

5. The spent coffee grounds demonstrated an influence on soil physical properties in the same way as other organic amendments reported in the literature (compost, manures, vegetable wastes, etc.).

6 . The use of spent coffee grounds as an organic amendment is a real possibility for improving the physical quality of Mediterranean agricultural soils. At the same time, it should be possible to reuse a waste product generated in such large amounts and contribute to the mitigation of climate change by incorporating carbon into soils.

Conflict of interest: The Authors declare no conflict of interest. 


\section{ACKNOWLEDGEMENTS}

This paper will form part of Ana Cervera-Mata's doctoral thesis, which is being developed within the context of the 'Nutrition and Food Sciences Programme' at the University of Granada.

\section{REFERENCES}

Abera K., Manahiloh K.N., and MotalledNejad M., 2017. The effectiveness of global thresholding techniques in segmenting two-phase porous media. Constr. Build. Mater., 142, 256-267. https://doi.org/10.1016/j.conbuildmat.2017.03.046

Aranda V., Calero J., Plaza I., and Ontiveros-Ortega A., 2016. Long-term effects of olive mill pomace co-compost on wettability and soil quality in olive groves. Geoderma, 267, 185-195. https://doi.org/10.1016/j.geoderma.2015.12.027

Aranyos J.T., Tomócsik A., Makádi M., Mészáros J. and Blaskó L., 2016. Changes in physical properties of sandy soil after long-term compost treatment. Int. Agrophys., 30, 269-274. https://doi.org/10.1515/intag-2016-0003

Bronick C.J. and Lal R., 2005. Soil structure and management: A review. Geoderma, 124, 3-22.

Calero J., Delgado R., Delgado G., and Martín-García J.M., 2009. SEM image analysis in the study of a soil chronosequence on fluvial terraces of the middle Guadalquivir (southern Spain). Eur. J. Soil Sci., 60, 465-480. https://doi. org/10.1111/j.1365-2389.2009.01131.x

Carter M.R., 2007. Long-term influence of compost on available water capacity of a fine sandy loam in a potato rotation. Can. J. Soil Sci., 87, 535-539. https://doi.org/10.4141/ cjss06042

Cervera-Mata A., Pastoriza S., Rufián-Henares J.A., Párraga J., Martín-García J.M. and Delgado G., 2018. Impact of spent coffee grounds as organic amendment on soil fertility and lettuce growth in two Mediterranean agricultural soils. Arch. Agron. Soil Sci., 64, 790-804. https://doi.org/10.1080 /03650340.2017.1387651

Cruz R., Baptista P., Cunha S., Pereira J.A., and Casal S., 2012. Carotenoids of lettuce (Lactuca sativa $\mathrm{L}$.) grown on soil enriched with spent coffee grounds. Molecules, 17, 1535-1547. https://doi.org/10.3390/molecules17021535

Cruz R., Gomes T., Ferreira A., MendesE., Baptista P., Cunha S., Pereira J.A., Ramalhosa E., and Casal S., 2014a. Antioxidant activity and bioactive compounds of lettuce improved by espresso coffee residues. Food Chem., 145, 95-101. https://doi.org/10.1016/j.foodchem.2013.08.038

Cruz R., Mendes E., Torrinha Á., Morais S., Pereira J.A., Baptista P., and Casal S., 2015. Revalorization of spent coffee residues by a direct agronomic approach. Food Res. Int., 73, 190-196. https://doi.org/10.1016/j.foodres.2014. 11.018

Cruz R., Morais S., Mendes E., Pereira J.A., Baptista P., and Casal S., 2014b. Improvement of vegetables elemental quality by espresso coffee residues. Food Chem., 148, 294299. https://doi.org/10.1016/j.foodchem.2013.10.059

Delgado R., Sánchez-Marañón M., Martín-García J.M., Aranda V., Serrano-Bernardo F., and Rosúa J.L., 2007. Impact of ski pistes on soil properties: A case study from a mountainous area in the Mediterranean region. Soil Use Manag., 23, 269-277. https://doi.org/10.1111/j.1475-2743. 2007.00093.x
Dexter A.R., 2004. Soil physical quality Part I. Theory, effects of soil texture, density, and organic matter, and effects on root growth. Geoderma, 120, 201-214. https://doi.org/10.1016/j. geoderma.2003.09.004

Diacono M. and Montemurro F., 2010. Long-term effects of organic amendments on soil fertility. A review. Agron. Sustain. Dev., 30, 401-422. https://doi.org/10.1051/ agro/2009040

Esmaeelnejad L., Shorafa M., Gorji M., and Hosseini S.M., 2016. Enhancement of physical and hydrological properties of a sandy loam soil via application of different biochar particle sizes during incubation period. Span. J. Agric. Res., 14. https://doi.org/10.5424/sjar/2016142-9190

Fadai N.T., Melrose J., Please C.P., Schulman A., and Van Gorder R.A., 2017. A heat and mass transfer study of coffee bean roasting. Int. J. Heat Mass Tran., 104, 787-799. https://doi.org/10.1016/j.ijheatmasstransfer.2016.08.083

Ferreira de Araújo A.S., Moura L., José de Melo W., dos Santos V.M. and Fernando de Araujo F., 2016. Soil properties and cowpea yield after six years of consecutive amendment of composted tannery sludge. Acta Sci-Agron., 38, 407-413. https://doi.org/10.4025/actasciagron.v38i3. 28281

Forge T., Kenney E., Hashimoto N., Neilsen D., and Zebarth B., 2016. Compost and poultry manure as preplant soil amendments for red raspberry: Comparative effects on root lesion nematodes, soil quality and risk of nitrate leaching. Agr. Ecosyst. Environ., 223, 48-58. https://doi. org/10.1016/j.agee.2016.02.024

Hardgrove S.J. and Livesley S.J., 2016. Applying spent coffee grounds directly to urban agriculture soils greatly reduces plant growth. Urban For. Urban Gree., 18, 1-8. https://doi. org/10.1016/j.ufug.2016.02.015

Hernández T., Garcia E. and García C., 2015. A strategy for marginal semiarid degraded soil restoration: A sole addition of compost at a high rate. A five-year field experiment. Soil Biol. Biochem., 89, 61-71. https://doi.org/10.1016/j. soilbio.2015.06.023

IUSS Working Group WRB, 2014. World Reference Base for Soil Resources 2014. International soil classification system for naming soils and creating legends for soil maps. World Soil Resources Reports No. 106. FAO, Rome. https://doi. org/10.1007/springerreference_76722

Kemper W.D. and Rosenau R.C., 1986. Aggregate stability and size distribution. In: Methods of Soil Analysis, Agronomy (Ed. A. Klute), Series, 9. ASA/SSSA, Inc., Madison,WI, USA. https://doi.org/10.2136/sssabookser5.1.2ed.c17

Khaliq A. and Abassi M.K., 2015. Improvements in the physical and chemical characteristics of degraded soils supplemented with organic-inorganic amendments in the Himalayan region of Kashmir, Pakistan. Catena, 126, 209-219. https:// doi.org/10.1016/j.catena.2014.11.015

Lal R., 2015. Restoring soil quality to mitigate soil degradation. Sustainability, 7, 5875-5895. https://doi.org/10.3390/ su7055875

Moreno M.T., Carmona E., de Santiago A., Ordovás J., and Delgado A., 2016. Olive husk compost improves the quality of intensively cultivated agricultural soils. Land Degrad. Dev., 27, 449-459. https://doi.org/10.1002/ldr.2410

Murthy P.S. and Naidu M.M., 2012. Sustainable management of 
coffee industry by-products and value addition - A review. Resour. Conserv. Recy., 66, 45-58. https://doi.org/10.1016/j. resconrec.2012.06.005

Mussatto S.I., Carneiro L.M., Silva J.P.A., Roberto I.C. and Teixeira J.A., 2011. A study on chemical constituents and sugars extraction from spent coffee grounds. Carbohydr. Polym., 83, 368-374. https://doi.org/10.1016/j.carbpol. 2010.07.063

Omondi M.O., Xia X., Nahayo A., Liu X., Korai P.K., and Pan, G., 2016. Quantification of biochar effects on soil hydrological properties using meta-analysis of literature data. Geoderma, 274, 28-34. https://doi.org/10.1016/j.geoderma. 2016.03.029

Reynolds W.D., Drury C.F., Yang X.M., and Tan C.S., 2008. Optimal soil physical quality inferred through structural regression and parameter interactions. Geoderma 146, 466474. https://doi.org/10.1016/j.geoderma.2008.06.017

Rodríguez Martín J.A., Álvaro-Fuentes J., Gonzalo J., Gil C., Ramos-Miras J.J., Grau Corbí J.M., and Boluda R., 2016. Assessment of the soil organic carbon stock in Spain. Geoderma, 264, 117-125. https://doi.org/10.1016/j. geoderma.2015.10.010

Sall S.N., Masse D., Hélène Diallo N., Sow T.M.B., Hien E., and Guisse A., 2016. Effects of residue quality and soil mineral $\mathrm{N}$ on microbial activities and soil aggregation in a tropical sandy soil in Senegal. Eur. J. Soil Biol., 75, 62-69. https://doi.org/10.1016/j.ejsobi.2016.04.009
Sánchez-Marañón M., Martín-García J.M., and Delgado R., 2011. Effects of the fabric on the relationship between aggregate stability and color in a Regosol-Umbrisol soil scape. Geoderma, 162, 86-95. https://doi.org/10.1016/j. geoderma.2011.01.008

Soil Survey Staff, 2014. Soil Survey Field and Laboratory Methods Manual, Soil Survey Investigations. Report No. 51, Version 2.0. (Eds R. Burt and Soil Survey Staff). U.S. Department of Agriculture, Natural Resources Conservation Service. https://doi.org/10.2136/sh1985.4.0034

Sonnleitner R., Lorbeer E., and Schinner F., 2003. Effects of straw, vegetable oil and whey on physical and microbiological properties of a Chernozem. Appl. Soil Ecol. 22, 195-204. https://doi.org/10.1016/s0929-1393(02)00159-2

Tokimoto T., Kawasaki N., Nakamura T., Akutagawa J., and Tanada S., 2005. Removal of lead ions in drinking water by coffee grounds as vegetable biomass. J. Colloid Interface Sci ., 281, 56-61. https://doi.org/10.1016/j.jcis.2004.08.083

Yamane K., Kono M., Fukunaga T., Iwai K., and Sekine R., 2014. Field Evaluation of Coffee Grounds Application for Crop Growth Enhancement, Weed Control, and Soil Improvement. Plant Prod. Sci., 17, 93-102. https://doi. org/10.1626/pps.17.93

Yazdanpanah N., Mahmoodabadi M., and Cerdà A., 2016. The impact of organic amendments on soil hydrology, structure and microbial respiration in semiarid lands. Geoderma, 266, 58-65. https://doi.org/10.1016/j.geoderma.2015.11.032 